\title{
Funerary colors in Pre-classical Maya culture: the red pigment in the 19th tomb of Rio Azul (Peten, Guatemala)
}

\author{
María Teresa Doménech-Carbó ${ }^{{ }^{*}}$, María Luisa Vázquez de Agredos-Pascual ${ }^{2 *}$ (], Laura Osete-Cortina ${ }^{1}$, \\ Antonio Doménech-Carbó ${ }^{3}$, Nuria Guasch-Ferré ${ }^{1,4}$ and Cristina Vidal-Lorenzo ${ }^{2}$
}

\begin{abstract}
The pigments were important in the funerary customs of the ancient Maya. They could be introduced as an offering inside the tombs or burials, and were also used to wrap the dead bodies, as if it were a funeral shroud. In the tombs and burials of royalty and high social classes the use of pigments for this purpose is well documented, and physicochemical studies are focused on their identification. This scientific contribution shows the results obtained when analyzing two reddish pigmenting materials from the grave goods of the tomb 19 of the archaeological site of Rio Azul, (Guatemalan Department of Petén), using a multi-technique approach including microscopy, diffraction, spectroscopic, electrochemical and chromatographic techniques. The results have enabled the identification of the inorganic and organic materials composing these pigmenting materials found in a ceramic posthumous offering dish and further discussion mainly has been focused on the geological source of the inorganic materials and the possible origin of the organic matter accompanying these two pigmenting materials.
\end{abstract}

Keywords: Funerary colors, Aromatics, Mesoamerica, Maya culture, Tomb 19, Rio Azul, Pre-Classic period

\section{Introduction}

Since Preclassic times the Mesoamerican ruling classes were buried in distinguished tombs containing ornaments of great economic and symbolic value such as jade, amber, obsidian, malachite, serpentine, motherof-pearl, turquoise and even gold. Alongside these precious objects, pigmenting substances were deposited inside vessels, dishes or clay urns placed surrounding the shrouded corpse, which have been interpreted as body colors and aromatics for accompanying the deceased after death to the other world, or for being used by the priests and leading dignitaries during officiating funerary

\footnotetext{
*Correspondence: tdomenec@crbc.uv.es; m.luisa.vazquez@uv.es

${ }^{1}$ Institut de Restauració del Patrimoni, Universitat Politècnica de València,

Camino de Vera s/n, 46022 Valencia, Spain

${ }^{2}$ Departament d'Historia de l'Art, Universitat de València, Avda. Blasco

Ibañez s/n, 46022 Valencia, Spain

Full list of author information is available at the end of the article
}

rites and posthumous ceremonies for the opening and dedication of these tombs [1].

A number of studies can be found in literature, which are focused on the characterization of pigmenting materials used as funerary colors or cosmetics in ancient civilizations worldwide. Thus, antimony sulphide $\left(\mathrm{Sb}_{2} \mathrm{~S}_{3}\right)$ and lead minerals such as cerussite $\left(\mathrm{PbCO}_{3}\right)$ or galena $(\mathrm{PbS})$ were used in Egypt for preparing cosmetics [2-4] and for their therapeutic properties for skin [5]. Pink colors from madder plants or black smoke to mark eyebrows and the contour of the eyelashes were used in Greek and Roman cultures [6, 7]. Magical properties were also attributed to cosmetics and thus, the use of pigments for religious posthumous ceremonies was also widespread worldwide [8-10]. Concerning Mesoamerican Pre-Columbian civilizations are scarce the number of analytical studies devoted to the characterization of funerary pigments found in literature. The authors, recently, have reported

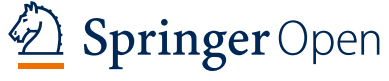

(c) The Author(s) 2020. This article is licensed under a Creative Commons Attribution 4.0 International License, which permits use, sharing adaptation, distribution and reproduction in any medium or format, as long as you give appropriate credit to the original author(s) and the source, provide a link to the Creative Commons licence, and indicate if changes were made. The images or other third party material in this article are included in the article's Creative Commons licence, unless indicated otherwise in a credit line to the material. If material is not included in the article's Creative Commons licence and your intended use is not permitted by statutory regulation or exceeds the permitted use, you will need to obtain permission directly from the copyright holder. To view a copy of this licence, visit http://creativeco mmons.org/licenses/by/4.0/. The Creative Commons Public Domain Dedication waiver (http://creativecommons.org/publicdomain/ zero/1.0/) applies to the data made available in this article, unless otherwise stated in a credit line to the data. 
the presence of a number of funerary colors and aromatic resins in a burial of a high-status individual in Teotihuacan [11]. This line of research has also brought interesting results in the Maya area [12].

The present article reports the chemical data obtained on two samples of funerary pigmenting materials included among the posthumous offerings that accompanied to a deceased presently of high status in the 19th tomb of the Rio Azul Maya archaeological site placed in the Guatemalan Department of Petén (Fig. 1a). The results presented have been obtained by means of a multi-technique approach including microscopy, diffraction, spectroscopic, electrochemical and chromatographic techniques. The chemical composition of the samples is discussed with a view to the alteration mechanisms that could take place, the geological and biological sources of both inorganic and organic materials identified and the ritual uses of the pigmenting materials.

\section{Experimental: materials and methods Material: funerary context of the samples}

The materials analyzed are currently exhibited and stored in the Museo Nacional de Arqueologia y Etnologia (MNAE) of Guatemala (Fig. 1b). These are the pigment samples preserved in the funerary offerings of this tomb (Fig. 1c, d). Figure 1b shows the replica of the tomb, as it has been exhibited at the Museo de Arqueología y Etnología of Guatemala. This tomb was excavated in the rock, and its interior was decorated with glyphs and figures in reddish hues, which contrast with the ochre of the background. The high dignitary buried here was deposited in a burial bed made of wood and cotton from the

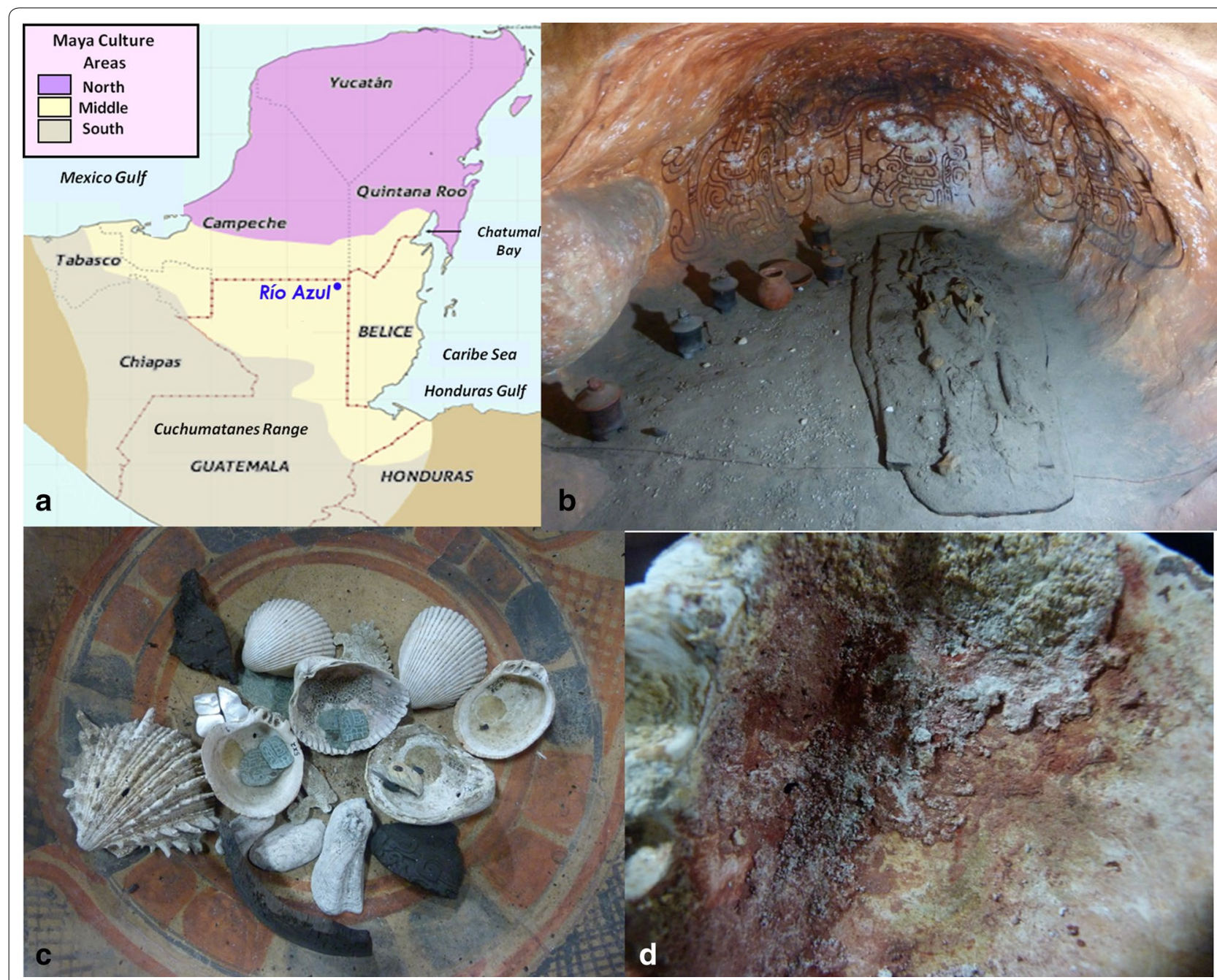

Fig. 1 a Location of the archaeological sites of Rio Azul, $\mathbf{b}$ replica of the burial 19 exhibited in the MNAE from Rio Azul, c image of the offerings placed in the polychromed ceramic dish placed close to the deceased, $\mathbf{d}$ detail of pigmenting material 2 
ceiba. In turn, his deceased body was surrounded by burial offerings, among which were numerous ceramic vessels. Among these ceramic vessels was the dish containing the pigment samples considered in this study. One of them was contained inside a shell (Fig. 1d). The presence of this mollusc, red pigments, and green stones that also appeared inside this dish identifies the high value of some of the burial offerings included in this tomb.

The archaeological site of Rio Azul is placed in the Northeastern part of the Petén Department (Guatemala) near the Mexico frontier and Belice, and dates back to the Maya Late-Preclassic period (250/300 a.C-250/300d.C) (see Fig. 1a). The pigmenting materials considered in this study were mainly minerals finely powdered contained in polychromed funerary dishes placed close to other offerings: fragments of a wooden vessel, marine shells, mother-of-pearl, Spondylus, thin plates of jadeite and small fragments of charcoal spread anywhere (Fig. 1b-d). Samples 1 and 2, respectively, consisted of brown-reddish and reddish pigmenting materials which appeared aggregated in small agglomerates (Fig. 2a-c).

\section{Methods}

The analytical protocol is based on the combination of several non destructive and micro-destructive instrumental techniques, namely, light microscopy (LM), scanning electron microscopy-X-ray microanalysis (SEM-EDX), X-ray diffraction (XRD), Ultraviolet-visible spectrophotometry (UV-vis spectrophotometry), Fourier transform infrared spectroscopy (FTIR spectroscopy), solid state square wave voltammetry (SQWV) and gas chromatography-mass spectrometry (GC-MS). The description of the scientific instruments used is presented below:

\section{Light microscopy}

A stereoscopic light microscope Leica GZ6 (X10-X50) was used for selecting the samples to be analyzed and a polarized light microscope Leica DM2500 P (Leica
Microsystems. Heidelberg, Germany) was used for morphological and petrographic examination of the minerals. Leica Digital FireWire Camera (DFC) with Leica Application Suite (LAS) software has been used for acquiring and processing the digital images. Samples were prepared by softly grinding a few micrograms of the pigmenting materials in a small agate mortar and then extended them on a slide and protected with a thin cover slide. Mounting medium was not used.

\section{Scanning electron microscopy-X-ray microanalysis}

Chemical composition of the minerals was obtained using a Jeol JSM 6300 scanning electron microscope operating with a Link-Oxford-Isis X-ray microanalysis system. The analytical conditions were: $20 \mathrm{kV}$ accelerating voltage, $2 \times 10^{-9}$ A beam current and $15 \mathrm{~mm}$ as working distance. Samples were carbon coated to eliminate charging effects. Quantitative microanalysis was carried out using the ZAF method for correcting interelemental effects. The counting time was $100 \mathrm{~s}$ for major and minor elements. The standards used were the following minerals: Albite $(\mathrm{Na}), \mathrm{MgO}(\mathrm{Mg}), \mathrm{Al}_{2} \mathrm{O}_{3}$ (Al), Quartz (Si), GaP (P), FeS ${ }_{2}(\mathrm{~S})$, MAD-10 feldspar (K), Fe (Fe), $\mathrm{Mn}(\mathrm{Mn})$, wollastonite $(\mathrm{Ca}), \mathrm{Ti}(\mathrm{Ti}), \mathrm{PbF}_{2}$ ( $\mathrm{Pb}), \mathrm{Hg}(\mathrm{HgTe}), \mathrm{Cl}(\mathrm{KCl})$, As (InAs). Element percentages were generated by ZAF soft-ware on the OxfordLink-Isis EDX.

Average chemical composition of the samples, consisting of several microcrystalline mineral phases, corresponds to the mean value obtained from triplicate quantitative measurements from an area of the powdered sample at ca. $100 \mu \mathrm{m}^{2}$. In parallel, quantitative spot measurements on the surface of individual grains and aggregates provided the chemical composition of the different mineralogical phases contained in the sample. Precision of measurements is given by the standard deviation. Detection limit for the studied elements was $0.01 \%$. Clay standards were used for checking SEM-EDX measurements.

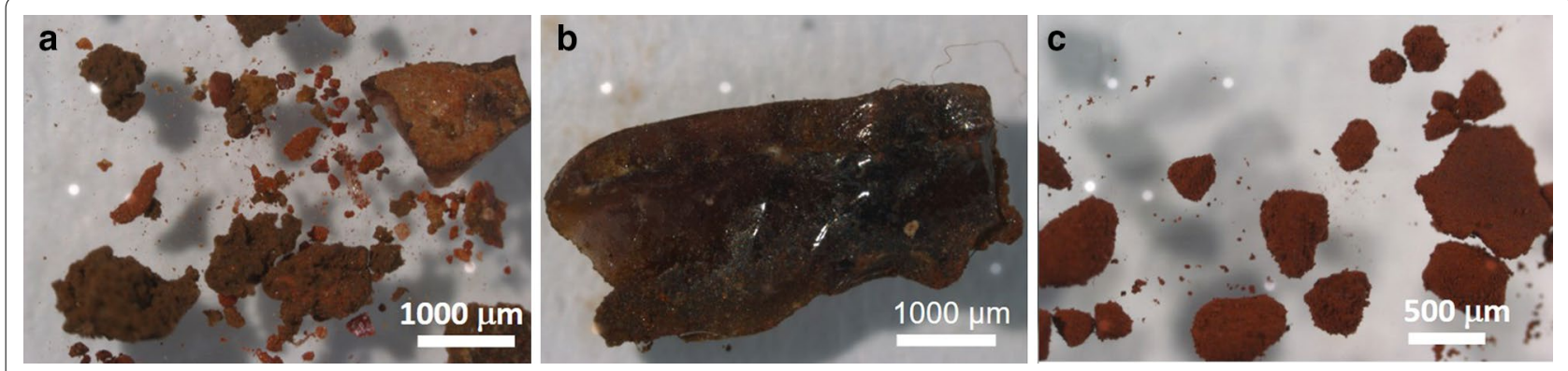

Fig. 2 Image obtained with sterescopic microscope of: a sample 1, b sample 2, c glassy fragment covered with reddish pigment 


\section{$X$-ray diffraction/X-ray microdiffraction}

XRD diffractograms were acquired by using a Bruker D8 Advanced A25 diffractometer equipped with a Lynxeye fast detector. XRD patterns were collected covering $5-80^{\circ} 2 \theta$ with an exposition time of $0.8 \mathrm{~s}$. $\mathrm{Cu} \mathrm{K \alpha}$ radiation was used ( $40 \mathrm{kV}$ and $40 \mathrm{~mA}$ ).

\section{FTIR spectroscopy}

The IR spectra in the ATR mode of the powdered samples were obtained using a Vertex 70 Fourier-transform infrared spectrometer with a FR-DTGS (fast recovery deuterated triglycine sulfate) temperature-stabilized coated detector and a MKII Golden Gate Attenuated Total Reflectance (ATR) accessory. Spectral interval scanned was $4000-500 \mathrm{~cm}^{-1}$. A total of 32 scans were collected at a resolution of $4 \mathrm{~cm}^{-1}$ and the spectra were processed using the OPUS/IR software.

\section{Voltammetry of microparticles (square wave voltammetry (SQWV)}

Paraffin-impregnated graphite electrodes were prepared as described in literature [13], and consisted on cylindrical rods of diameter $2 \mathrm{~mm}$. Samples of funerary pigments were scraped with the help of a scalpel and then, an amount of at ca. 10-20 $\mu \mathrm{g}$ of these materials was powdered in an agate mortar and pestle and further extended on the agate mortar forming a spot of finely distributed material. Then the lower end of the graphite electrode was gently rubbed over that spot of sample and finally rinsed with water to remove ill-adhered particles.

Electrochemical experiments were performed at $298 \mathrm{~K}$ in a three-electrode cell after 10-15 min bubbling of Ar. Square wave voltammograms (SQWVs) and complementary cyclic voltammograms (CVs) were obtained with a $\mathrm{CH}$ 660I equipment. Paraffin-impregnated graphite working electrodes were dipped into the electrochemical cell so that only the lower end of the electrode was in contact with the electrolyte solution. This procedure provides an almost constant electrode area and reproducible background currents. $\mathrm{An} \mathrm{AgCl}(3 \mathrm{M} \mathrm{NaCl}) / \mathrm{Ag}$ reference electrode and a platinum-wire auxiliary electrode completed the conventional three-electrode arrangement. $0.50 \mathrm{M}$ acetic acid plus sodium acetate aqueous buffer (pH 4.75) and $0.10 \mathrm{M} \mathrm{HCl}$ were used as electrolytes.

\section{Gas chromatography-mass spectrometry}

Three methods of derivatization were applied in order to identify organic matter present in the samples. In the first one for lipids and proteins [14] a small amount of sample $(0.5 \mathrm{mg})$ was grinded and placed in a $0.3 \mathrm{~mL}$ minivial (Supelco Bellefonte, PA, USA) and hydrolyzed with 100 $\mu \mathrm{L}$ of $6 \mathrm{M} \mathrm{HCl}$ in an $\mathrm{Ar}$ atmosphere for $24 \mathrm{~h}$ at $110^{\circ} \mathrm{C}$. The resulting solution was evaporated to dryness under infrared radiation lamp (230 V, $250 \mathrm{~W}$, Osram Siccatherm, Germany) and then $100 \mu \mathrm{L}$ of water and $100 \mu \mathrm{L}$ of $\mathrm{CHCl}_{3}$ were added, shaking vigorously to facilitate the extraction of fatty acids in the chloroformic phase. The aqueous and chloroformic phases were separated and treated independently as described below. Proteinaceous components in the samples are best separated in the aqueous phase. $50 \mu \mathrm{L}$ of ethanol/pyridine $4: 1$ were added to $50 \mu \mathrm{L}$ of aqueous phase. This solution was treated with $8 \mu \mathrm{L}$ of ethyl chloroformate (ECF), shaking for $10 \mathrm{~s}$ after the addition to help the reaction. The reaction mixture was then extracted with $50 \mu \mathrm{L}$ of $1 \% \mathrm{CHCl}_{3}$ in $\mathrm{ECF}$ and, finally, $50 \mu \mathrm{L}$ of a saturated solution of $\mathrm{NaHCO}_{3}$ was added and shaken vigorously. Two phases (aqueous and chloroformic) were obtained and $1.5 \mu \mathrm{L}$ of the organic phase was injected into the chromatograph. The same process was followed for the chloroformic phase, which was first evaporated to dryness and the residue redissolved in $50 \mu \mathrm{L}$ of a water/ethanol/pyridine mixture (5:4:1). In the analyses was used a gas chromatograph Agilent $6890 \mathrm{~N}$ (Agilent Technologies, Palo Alto, Ca, USA) equipped with an on-column injection system and coupled with an Agilent $5973 \mathrm{~N}$ mass spectrometer (Agilent Technologies). A capillary column HP-5MS (5\% phenyl-95\% methylpolysiloxane, $30 \mathrm{~m} \times 0.25 \mathrm{~mm}$ I.D., 0.25 $\mu \mathrm{m}$ film thickness, Agilent Technologies) was used in order to provide an adequate separation of components for analysis. The chromatographic conditions used for the analysis of the chloroformic phase were: initial temperature of the gas chromatograph $50^{\circ} \mathrm{C}$ held for $2 \mathrm{~min}$, a gradient of $20{ }^{\circ} \mathrm{C} \mathrm{min}-1$ up to $300{ }^{\circ} \mathrm{C}$, which was held for $12 \mathrm{~min}$. Helium glass flow in constant mode was set at $1.3 \mathrm{~mL} \mathrm{~min}^{-1}$ and a split ratio of 1:20. For the aqueous phase initial temperature of the gas chromatograph was $100{ }^{\circ} \mathrm{C}$, a gradient of $5{ }^{\circ} \mathrm{C} \mathrm{min}-1$ up to $155^{\circ} \mathrm{C}$, ramping up at $15{ }^{\circ} \mathrm{C} \min ^{-1}$ up to $295^{\circ} \mathrm{C}$, which was held for $5 \mathrm{~min}$. Ions were generated by electron ionisation $(70 \mathrm{eV})$ in the ionisation chamber of the mass spectrometer. The mass spectrometer was scanned from $\mathrm{m} / \mathrm{z} 20$ to $\mathrm{m} / \mathrm{z} 800$, with a cycle time of one second. Tuning of the mass spectrometer was checked using perfluoro-tributylamine. Agilent ChemStation software G1701CA MSD was used for GC-MS control, peak integration and mass spectral evaluation. EI mass spectra were acquired in the total ion monitoring mode and peak area data from total ion current (TIC) chromatograms were used for calculating the ratio stearic to palmitic acid content. The temperatures of the interface and the source were 280 and $150{ }^{\circ} \mathrm{C}$, respectively. The Wiley and NIST Libraries of Mass Spectra were used for identifying the compounds.

Secondly, for terpenoid resins was applied the method of direct silylation [11] previously used with success in Mesoamerican archaeological samples of funerary 
pigments and binding medium of Maya wall paintings. For polysaccharides was applied the method of methylation-silylation [15].

\section{Results and discussion}

\section{Characterization of minerals}

Table 1 summarizes the main signatures from FTIR spectroscopy, SEM-EDX, SQWV and XRD (diffractograms are illustrated in Fig. 3a, b), which have been used for identifying the more relevant minerals present in the studied samples of funerary pigments. Table 2 shows the average values of chemical composition obtained by SEM-EDX whereas Table 3 summarizes the minerals identified in each one of the samples studied.

Reddish samples 1 and 2 from Rio Azul, exhibited reflectance spectra slightly different. Figure 4a shows the reflectance spectrum (continuous line) obtained in the visible region for sample 1, which exhibits a brown-reddish hue at naked eye. The spectrum of this archaeological pigment is dominated by a broad band in the range $570-750 \mathrm{~nm}$ with a maximum of reflectance at $690 \mathrm{~nm}$ and a secondary maximum at $635 \mathrm{~nm}$. The spectrum of this sample satisfactorily fits those others of vermilion (mineralogically cinnabar) (dotted line) and iron oxide red (haematite) showed in Fig. $4 \mathrm{~b}$ if they are overlapped, thus suggesting that these two minerals are mainly contributing to the colour of the sample despite they are not major components of the sample. A second narrow and weak band in the $400-450 \mathrm{~nm}$ violet-blue region is also recognized. Combination of these two reflectance bands in the red and blue regions results in a brown-reddish colour, which is in agreement with the visual appearance of the sample. It is of worth to mention that this spectrum exhibits notably high values of reflectance up to $90 \%$ in the entire visible interval of this sample. This high reflectance is associated to the presence of calcite as major component of the sample as well as the presence of a glassy mineral in the sample (vide infra). Figure $4 \mathrm{~b}$ shows the visible spectrum obtained in sample 2 . The spectral profile of this sample satisfactorily fits that of cinnabar (dashed line) overlapped with iron oxide red pigment (haematite) (dotted line) suggesting that these are the main mineral components present in this sample (vide infra).

Sample 1 is mainly composed of calcite $(77 \% \mathrm{CaO})$ whereas a mixture of calcite, iron oxide and cinnabar (19.97\% $\mathrm{CaO}, 34 \% \mathrm{HgO}, 15.62 \% \mathrm{FeO}$ ) conforms sample 2. Quartz, clayey minerals and grains of fibrous and platy texture, which exhibit a $\mathrm{P}$ - and Ca-rich composition, were also present at minor or trace level. $\mathrm{Ca} / \mathrm{P}$ molar

Table 1 Summary of characteristic signatures from FTIR spectroscopy, SEM-EDX, SQWV and XRD for the minerals identified in samples 1 and 2 of funerary pigments found in the Rio Azul tomb

\begin{tabular}{|c|c|c|c|c|}
\hline $\begin{array}{l}\text { Mineral } \\
\text { (Ideal Chemistry) }\end{array}$ & $\begin{array}{l}\text { SEM-EDX } \\
\text { Main emission lines } \\
\text { identified }\end{array}$ & $\begin{array}{l}\text { VMP } \\
\text { Main Cathodic and anodic } \\
\text { peaks } \\
(\mathrm{mV})\end{array}$ & $\begin{array}{l}\text { FTIR spectroscopy } \\
\text { Wave numbers } \\
\left(\mathrm{cm}^{-1}\right)\end{array}$ & $\begin{array}{l}\text { XRD } \\
\text { d-spacing } \\
(\AA)\end{array}$ \\
\hline $\begin{array}{l}\text { Calcite } \\
\mathrm{CaCO}_{3}\end{array}$ & Calcium: $\mathrm{K}_{\alpha}(\mathrm{Ca}), \mathrm{K}_{\beta}(\mathrm{Ca})$ & - & $1394,870,710$ & $3.033,2.285,2.095,1.913$ \\
\hline $\begin{array}{l}\text { Gaylussite } \\
\mathrm{Na}_{2} \mathrm{Ca}\left(\mathrm{CO}_{3}\right)_{2}\end{array}$ & $\begin{array}{l}\text { Calcium: } K_{a}(\mathrm{Ca}), K_{\beta}(\mathrm{Ca}) \\
\text { Sodium: } K_{a}(\mathrm{Na})\end{array}$ & - & $1403,870,710$ & - \\
\hline $\begin{array}{l}\text { Cinnabar } \\
\mathrm{HgS}\end{array}$ & $\begin{array}{l}\text { Sulphur: } K_{a}(S) \\
\left.\text { Mercury: } M_{a}(H g), L_{a} H g\right), L_{\beta} \\
\quad(H g)\end{array}$ & $\begin{array}{l}\text { Cathodic peak: + 30; Anodic } \\
\text { peak: }-450\end{array}$ & - & $3.359,2.865,2.027,1.980$ \\
\hline $\begin{array}{l}\text { Galena } \\
\text { PbS }\end{array}$ & $\begin{array}{l}\text { Sulphur: } K_{a}(S) \\
\text { Lead: } M_{a}(P b), L_{a}(P b), L_{\beta}(P b)\end{array}$ & - & - & - \\
\hline $\begin{array}{l}\text { Goethite } \\
\mathrm{FeO}(\mathrm{OH})\end{array}$ & Iron: $\mathrm{K}_{a}(\mathrm{Fe}), \mathrm{K}_{\beta}(\mathrm{Fe})$ & $\begin{array}{l}\text { Cathodic peaks: }+150 \text { and } \\
\quad-200\end{array}$ & - & - \\
\hline $\begin{array}{l}\text { Haematite } \\
\mathrm{Fe}_{2} \mathrm{O}_{3}\end{array}$ & Iron: $\mathrm{K}_{a}(\mathrm{Fe}), \mathrm{K}_{\beta}(\mathrm{Fe})$ & Cathodic peak: - 400 & 570,550 & $2.702,2.519,1.842,1.696$ \\
\hline $\begin{array}{l}\text { Halloysite/kaolinite } \\
\mathrm{Al}_{2} \mathrm{Si}_{2} \mathrm{O} 5(\mathrm{OH})_{4}\end{array}$ & $\begin{array}{l}\text { Aluminum: } \mathrm{K}_{a}(\mathrm{Al}) \\
\text { Silicon: } \mathrm{K}_{\mathrm{a}}(\mathrm{Si})\end{array}$ & - & $\begin{array}{l}3693,3671,3653,3623,3410 \\
1640,1163,1113,1029,1006 \\
937,910,795,779,753,687 \\
533\end{array}$ & $\begin{array}{l}\text { Halloysite: } 7.522,4.451,3.633 \text {, } \\
2.568 \\
\text { Kaolinite: } 7.179,3.576,2.341 \text {, } \\
\quad 1.486\end{array}$ \\
\hline $\begin{array}{l}\text { Hydroxylapatite } \\
\mathrm{Ca}_{5}\left(\mathrm{PO}_{4}\right)_{3}(\mathrm{OH})\end{array}$ & $\begin{array}{l}\text { Phosphor: } K_{a}(P) \\
\text { Calcium: } K_{a}(C a), K_{\beta}(C a)\end{array}$ & - & $1021,638,593$ & - \\
\hline $\begin{array}{l}\text { Quartz } \\
\mathrm{SiO}_{2}\end{array}$ & Silicon: $K_{a}(S i), K_{\beta}(S i)$ & - & $\begin{array}{l}1163,1150,1085,798,780 \\
695,514\end{array}$ & $4.259,3.343,1.817,1.541$ \\
\hline $\begin{array}{l}\text { Whewellite } \\
\mathrm{Ca}_{2} \mathrm{C}_{2} \mathrm{O}_{4} \cdot \mathrm{H}_{2} \mathrm{O}\end{array}$ & - & - & $1617,1315,779$ & - \\
\hline
\end{tabular}



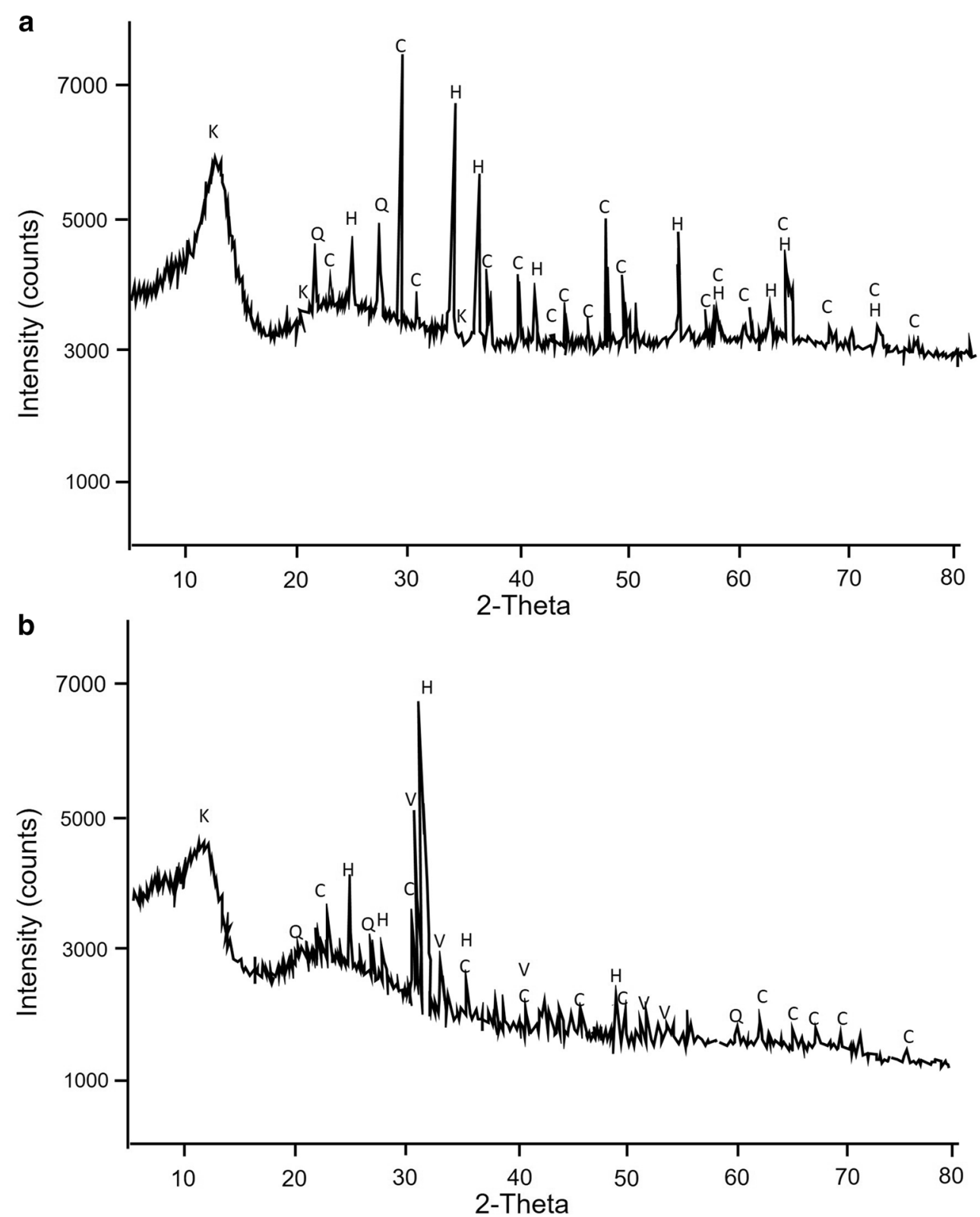

Fig. 3 Diffractograms of: a sample 1; b sample 2. K: clays halloysite/kaolinite; C: calcite; H: haematite; V: cinnabar; Q: quartz

ratio value obtained by punctual analysis in these grains is 1.8 for sample 1 and 1.67 for sample 2. These values satisfactorily match the theoretical value for hydroxylapatite $\left(\mathrm{Ca}_{5}\left(\mathrm{PO}_{4}\right)_{3}(\mathrm{OH}), \mathrm{Ca} / \mathrm{P}\right.$ molar ratio: 1.67). Weak signal of chlorine is also recognized in the X-ray spectrum of sample 1, which is associated to the presence of alkaline chloride salts. Small amounts of cinnabar and iron oxides and, eventually, some grains of galena $(\mathrm{PbS})$, were also found in sample 1 . Arsenic was accompanying mercury in grains of cinnabar. From the X-ray microanalysis performed in a large fragment of translucent vitreous appearance and dark color present in sample 1 (Fig. 2b) could be calculated an average molar proportion of $\mathrm{Na}_{0.59} \mathrm{Mg}_{0.13} \mathrm{~K}_{0.01} \mathrm{Ca}{ }_{0.08} \mathrm{Mn}_{0.02} \mathrm{Al}_{0.02} \mathrm{Si}_{1.2} \mathrm{O}_{2.95}$. The low value of aluminum and the major presence of sodium suggest that it could be a fragment of glass severely corroded. The glassy morphology and chemical composition characteristic of a glass found in sample 1 could be attributed to a natural glass of volcanic origin such as obsidian.

IR absorption spectra obtained in attenuated total reflectance (ATR) mode in these samples (Fig. 5a, b) confirmed that calcite is present in both samples in 
Table 2 Mean values of oxide percentage and their standard deviation (in brackets) obtained by SEMEDX in in samples 1 and 2 of funerary pigments found in the Rio Azul tomb

\begin{tabular}{llll}
\hline $\begin{array}{l}\text { Sample Ref. } \\
\text { (oxide wt \%) }\end{array}$ & $\mathbf{1}$ & $\mathbf{1 F}^{\mathbf{a}}$ & $\mathbf{2}$ \\
\hline $\mathrm{Na}_{2} \mathrm{O}$ & $11(2)$ & $17.9(0.9)$ & $<0.01$ \\
$\mathrm{MgO}$ & $0.67(0.11)$ & $4.74(0.18)$ & $<0.01$ \\
$\mathrm{Al}_{2} \mathrm{O}_{3}$ & $0.46(0.12)$ & $1.4(0.9)$ & $0.9(0.9)$ \\
$\mathrm{SiO}_{2}$ & $1.6(0.3)$ & $71(1)$ & $8(1)$ \\
$\mathrm{K}_{2} \mathrm{O}$ & $0.2(0.2)$ & $0.30(0.05)$ & $<0.01$ \\
$\mathrm{CaO}$ & $77(2)$ & $4.5(0.5)$ & $19.97(0.16)$ \\
$\mathrm{TiO}_{2}$ & - & - & $<0.01$ \\
$\mathrm{FeO}$ & $2.1(0.8)$ & $0.20(0.01)$ & $15.62(0.03)$ \\
$\mathrm{SO}_{3}$ & $1.9(0.8)$ & - & $13.96(0.08)$ \\
$\mathrm{Cl}$ & $<0.01$ & - & - \\
$\mathrm{P}_{2} \mathrm{O}_{5}$ & $0.3(0.3)$ & $<0.01$ & $2.3(2)$ \\
$\mathrm{HgO}$ & $3(2)$ & - & $34.0(0.4)$ \\
$\mathrm{PbO}$ & $<0.01$ & - & $<0.01$ \\
$\mathrm{MnO}$ & - & $1.4(0.6)$ & $<0.01$ \\
$\mathrm{As}_{2} \mathrm{O}_{3}$ & $<0.01$ & - & $3.65(0.18)$ \\
\hline
\end{tabular}

a $1 \mathrm{~F}$ : glassy fragment in sample 1

significant amount with intense bands at 1403 (sample1) 1398 (sample 2), 870 and $711 \mathrm{~cm}^{-1}$ associated with group vibrations $v_{3}, v_{2}$ and $v_{4}$, respectively, and weak band at $1798 \mathrm{~cm}^{-1}$ from the $\mathrm{CO}_{3}$ group vibrations $\left(v_{1}+v_{4}\right)$ [16]. A broad band in the range $3800-2500 \mathrm{~cm}^{-1}$ can be attributed to the stretching vibration of $\mathrm{OH}$ and $\mathrm{H}_{2} \mathrm{O}$ species with varying degrees of hydrogen bonding interactions associated to clay and clayey minerals of aluminium silicate type. Similar ascription to bending vibration is made to the shoulder at $1640 \mathrm{~cm}^{-1}$ [17]. Moderate band is also occurring at $1029 \mathrm{~cm}^{-1} \mathrm{~cm}^{-1}$ with shoulders at 1168,1089 and $942 \mathrm{~cm}^{-1}$ associated with the stretching vibrations of $\mathrm{Si}-\mathrm{O}$ and $\mathrm{Si}-\mathrm{O}-\mathrm{Al}$ bonds in silicates and aluminosilicates, whereas bands at 790 and $778 \mathrm{~cm}^{-1}$ are ascribed to the OTZ doublet of siliceous minerals [18]. Whewellite (mono hydrated calcium oxalate) is recognized in both samples by their asymmetric and symmetric stretching vibrations of -COO group at 1620 and $1318 \mathrm{~cm}^{-1}$ [19]. Apatite/hydroxylapatite (weak bands at 608 and $563 \mathrm{~cm}^{-1}$ ) is tentatively identified in sample 2 [20, 21]. The IR spectrum of sample 2 also confirms the presence of anhydrous iron oxide (bands at 528 and $558 \mathrm{~cm}^{-1}$ ) [22].

SQWV confirmed presence of cinnabar in sample 2 by the well-defined cathodic $\mathrm{Hg}$ reduction peak (II) at ca. $+0.03 \mathrm{~V}$ (Fig. 6a) [11]. Presence of haematite is also confirmed in both samples (Fig. 6b) by its characteristic haematite-to- $\mathrm{Fe}^{2+}$ ion reductive dissolution signal (II) at $-0.40 \mathrm{~V}$ [23], accompanied by weaker overlapping signals (III) in the +0.15 to $-0.20 \mathrm{~V}$ range, attributable to goethite forms with variable degree of crystallinity and hydration in sample 2 [24]. The presence of cinnabar was also confirmed by a well-defined stripping peak at $-0.45 \mathrm{~V}$ observed in the voltammogram recorded upon scanning the potential in the positive direction in acetate buffer [25]. Note that mineralogical identification of this last mineral could exclusively be carried out with SQWV in this research.

Table 3 Summary of compounds identified in samples 1 and 2 of funerary pigments found in the Rio Azul tomb

\begin{tabular}{|c|c|c|c|}
\hline Sample & Major components & Minor components & Remarks \\
\hline 1 & $\begin{array}{l}\text { Calcite } \\
\text { Corroded glass fragment }\end{array}$ & $\begin{array}{l}\text { Quartz } \\
\text { Clays } \\
\text { Gaylussite } \\
\text { Haematite } \\
\text { Cinnabar (arsenic sulphide) } \\
\text { Galena } \\
\text { Whewellite } \\
\text { Hydroxylapatite } \\
\text { Alkaline chloride }\end{array}$ & $\begin{array}{l}\text { Presence } \\
\text { of small } \\
\text { amounts } \\
\text { of organic } \\
\text { matter }\end{array}$ \\
\hline 2 & $\begin{array}{l}\text { Cinnabar (arsenic sulphide) } \\
\text { Haematite } \\
\text { Calcite }\end{array}$ & $\begin{array}{l}\text { Quartz } \\
\text { Hydroxylapatite } \\
\text { Clays } \\
\text { Goethite } \\
\text { Whewellite } \\
\text { Alkaline sulphate }\end{array}$ & $\begin{array}{l}\text { Presence } \\
\text { of small } \\
\text { amounts } \\
\text { of organic } \\
\text { matter }\end{array}$ \\
\hline
\end{tabular}



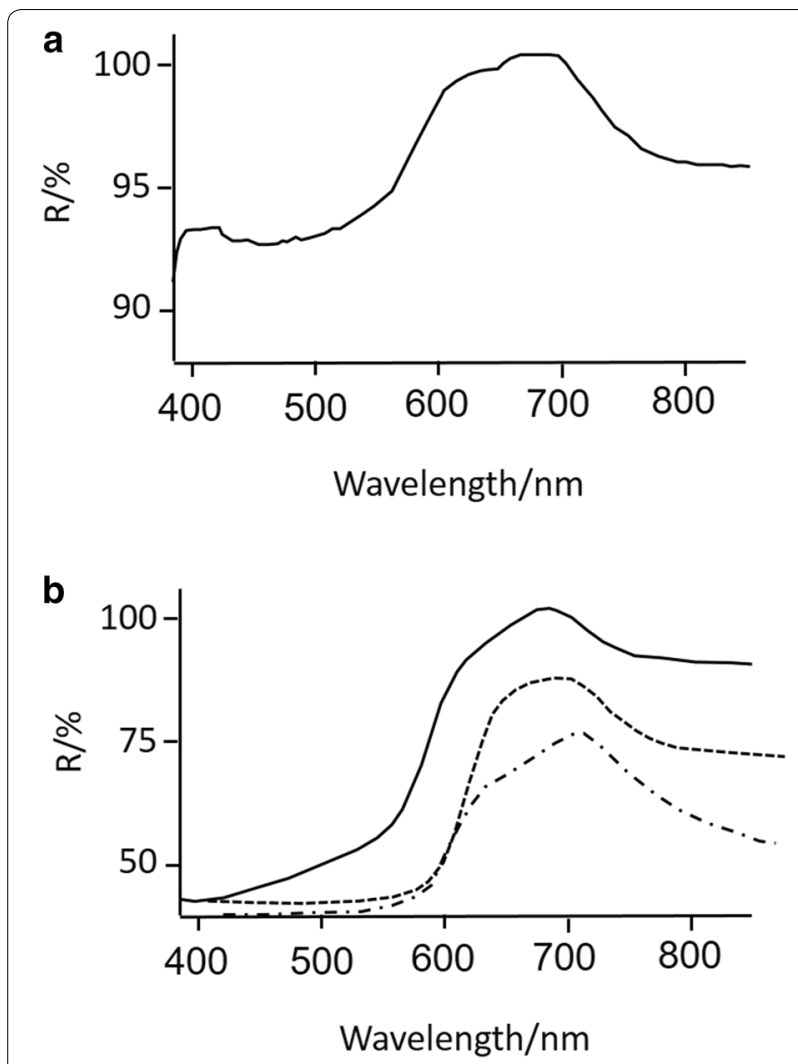

Fig. 4 Vis spectra of samples: $\mathbf{a} 1$ and $\mathbf{b} 2$ are presented as continuous lines. Spectrum of iron oxide red (dotted line) and vermilion (dashed line) (both supplied by Kremer pigmente $\odot$ ) are also showed in $\mathbf{b}$

\section{Characterization of organic materials}

Fatty matter in samples from Rio Azul was recognized in their IR spectra (Fig. 5a, b) by weak bands at 2920 and 2858 ascribed to the stretching vibrations of methyl and methylene groups and by the band at $1713 \mathrm{~cm}^{-1}$ associated to the stretching vibration of carbonyl groups of free fatty acids. A shoulder at $1514-70 \mathrm{~cm}^{-1}$ ascribed to metal-carboxylates formed by complexation of the fatty acids hydrolyzed from the sample lipids with calcium or other metallic species from the minerals present in the samples such as lead or manganese can be identified in the IR spectra [26].

No evidence of proteinaceous materials, natural resins and polysaccharides was found in samples from Rio Azul. GC "fingerprint" obtained in these samples (Fig. 7a) showed ethyl esters of a number of medium and long chain fatty acids, namely, decanedioic acid (sebacic acid), tetradecanoic acid (miristic acid), hexadecanoic acid (palmitic acid), 9-octadecenoic acid (cis/trans) and octadecanoic acid (stearic acid). The chromatogram of a laboratory blank showed in Fig. $7 \mathrm{~b}$ excludes that the compounds identified are laboratory contamination.
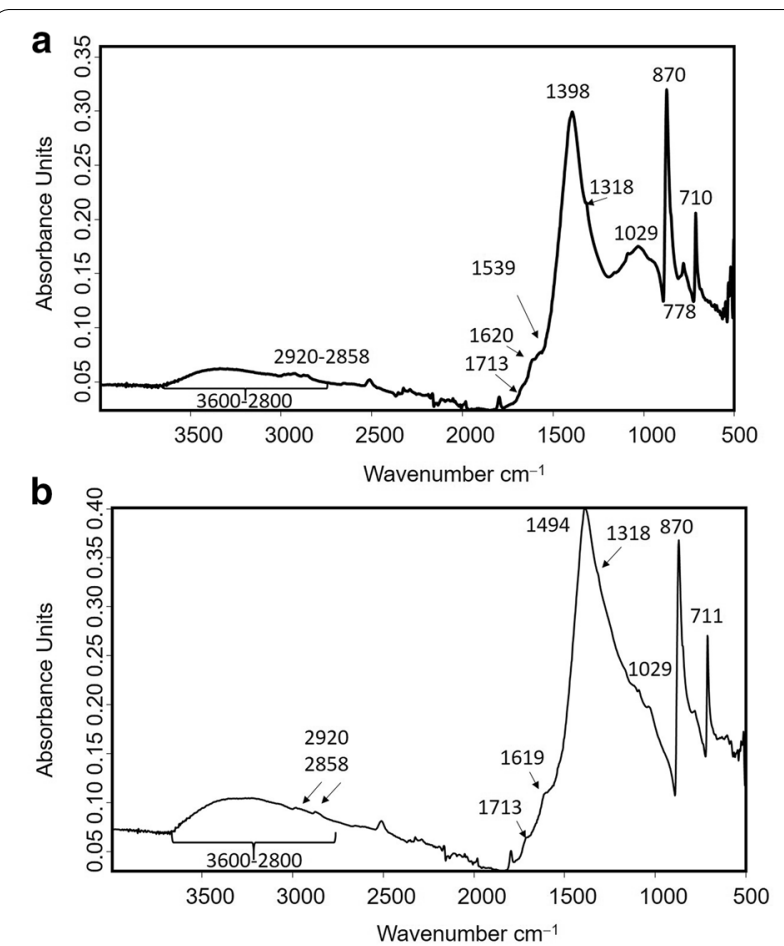

Fig. 5 IR absorption spectra obtained in ATR mode in: a reddish sample $1 ; \mathbf{b}$ red sample 2

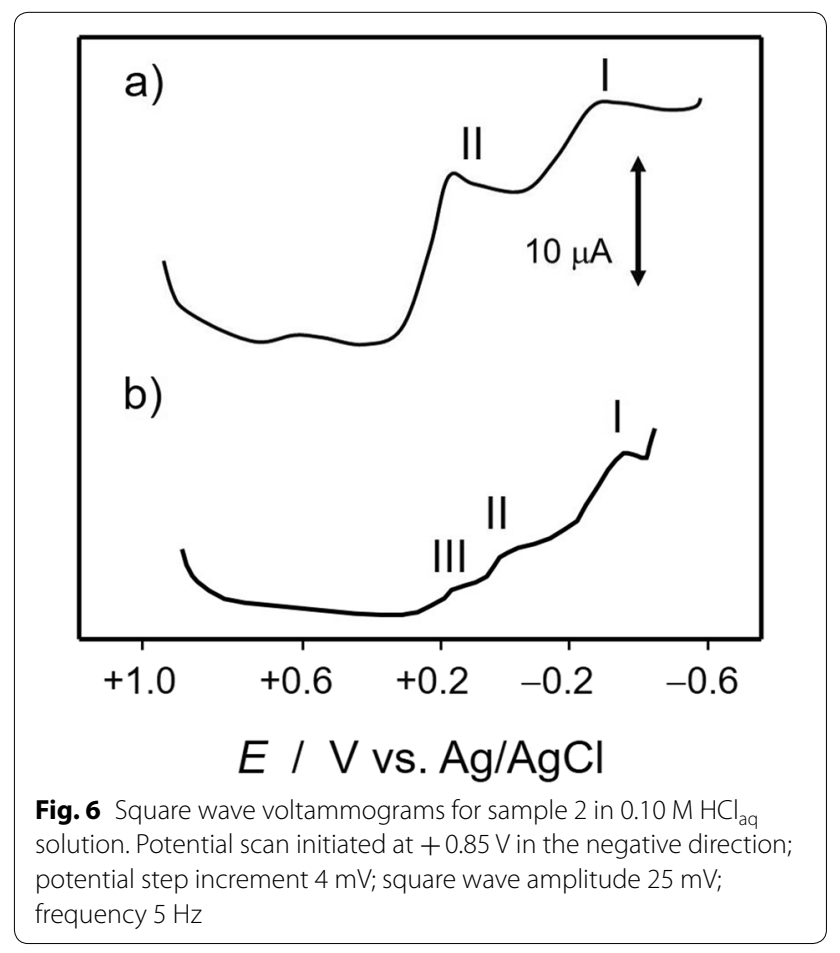



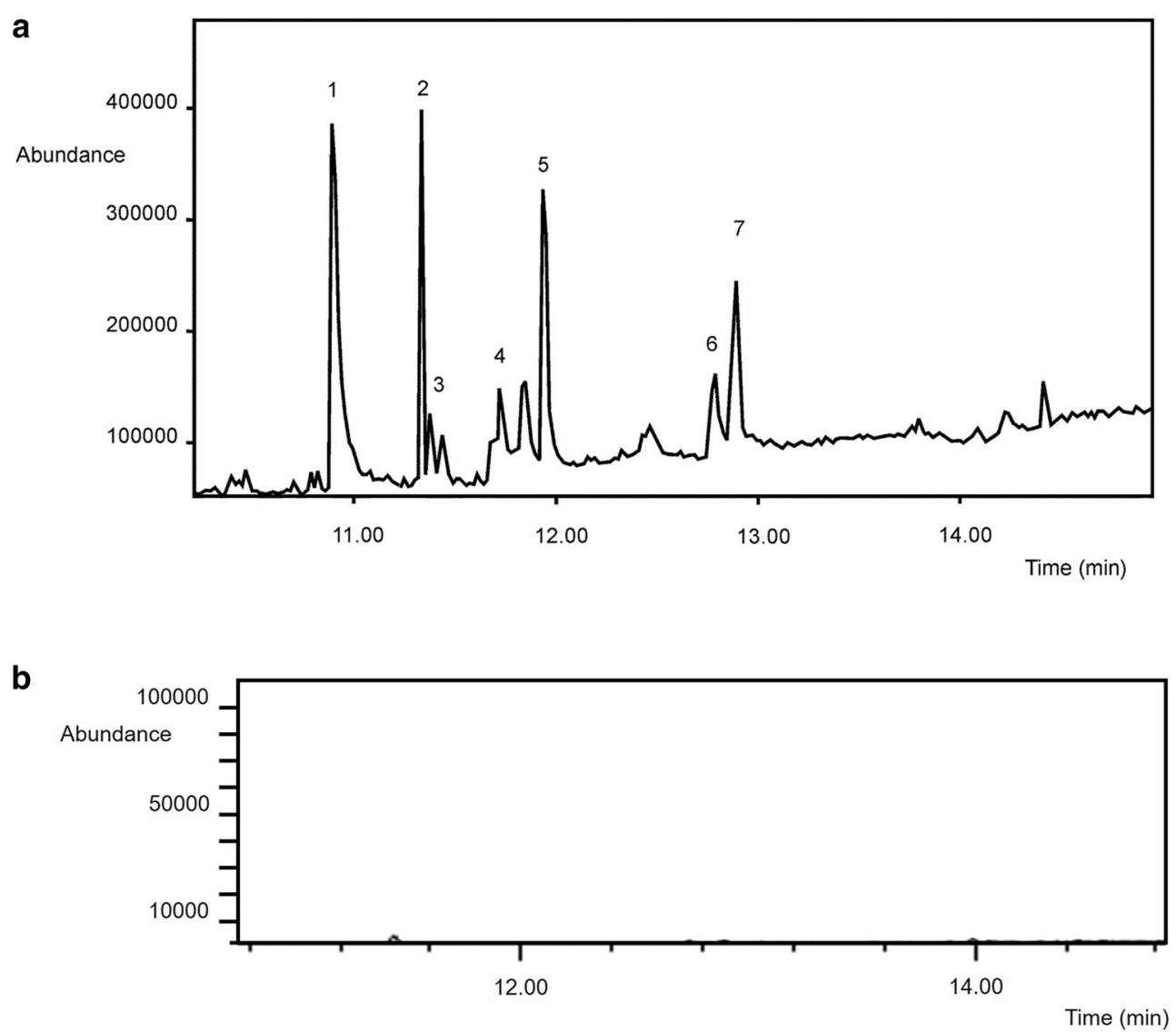

Fig. 7 a Chromatogram of the chloroform phase from sample 2. Compounds identified: (1) decanedioic acid, ethyl ester; (2) compound of diene conjugated type; (3) tetradecanoic acid, ethyl ester; (4) isomer of compound 2; (5) hexadecanoic acid, ethyl ester; (6) cis/trans 9-octadecenoic acid, ethyl ester; (7) octadecanoic acid, ethyl ester; b chromatogram of the laboratory blank

Environmental blank was not taken as the pigments were placed on ceramic dishes and stakeholders did not permit to excise a fragment of these ceramic pieces due to their uniqueness and fragility. It is of worth to note that the pigments studied were not in contact with the soil surrounding the tomb or with the deceased. During centuries the pigments only were exposed to the atmosphere of the tomb that was maintained as a hermetic air environment until the excavation of the archaeological site took place. Therefore, environmental contamination due to soil contact, usually found in other burials, is so improbable. This last hypothesis is discussed in the following section.

\section{Discussion}

\section{Archaeological source of the pigmenting materials}

The two studied samples are mainly composed of calcite with moderate presence of quartz and small amounts of clayey minerals. Variable amounts of cinnabar and iron oxides, mainly haematite, are responsible of the redorange hue exhibited by these materials.
The $\mathrm{Ca} / \mathrm{P}$ molar ratio values found in some $\mathrm{P}-\mathrm{Ca}$ rich grains satisfactorily fit the theoretical values for hydroxylapatite/apatite compounds. Then, this $\mathrm{P}-\mathrm{Ca}$ rich materials can be associated rather to environmental contamination. The latter due to burning practices in funerary rituals as abundant fragments of burnt materials were found spread surrounding the offerings placed close to the deceased. It has been reported that burning of organic materials was part of the funerary rites and posthumous rituals of high-status individuals in ancient Mesoamerican cultures [27-29]. A less probable origin should be associated to an authigenic mineral formed by the reaction of limestone with phosphatic solutions derived from animal excrements and guano commonly present in shelters, caves and less frequently in outcrops [30] with the intervention of microorganisms, prevalently bacteria and fungi [31]. These processes result in the precipitation of the hydroxylapatite via a number of phosphate intermediates or precursors depending on the $\mathrm{pH}$, degree of sobresaturation and chemical process. 
Maya culture was characterized by the special religious symbolism of caves (abundant in this region) and it has been reported that most of the pigments used for decorating their most relevant monuments and tombs were obtained from caves [32]. A diverse suite of karst landforms occurs in the area of the Ixcan Northeast Basin, which includes elaborate cave systems. This rugged and heterogeneous karst terrain has been formed on an older sequence of Cretaceous-Paleogen carbonate rocks known as Petén karst plateau and Lowlands [33]. The fact that the archaeological site is located in the karst plateau supports the hypothesis that the hydroxyapatite could be associated to caves, shelters and outcrops.

The metalogenetic distribution of the Department of Petén, with sources of different metals such as W, $\mathrm{Fe}, \mathrm{Cu}, \mathrm{Au}, \mathrm{Cr}, \mathrm{Pb}, \mathrm{Hg}, \mathrm{Mn}$ and $\mathrm{S}$ located not far Rio Azul, in particular, in Uaxactún, Buena Vista and Paso Caballos, justifies the chemical composition rich in hematite and cinnabar accompanied of small amounts of galena, found in the samples [34].

It is feasible this metalogenetic distribution to be found in the geological regions surrounding the Central American volcanic arc taking into account that the minerals identified in this study are formed in hydrothermal environments at low temperature which are linked to the presence of residual magmatic fluids [35].

Different origin seems to have the small fragment of glassy morphology and chemical composition characteristic of glass found in sample 1. Occurrence of obsidian, a natural glass of volcanic origin, has been frequently reported in archaeological sites of Mesoamerican region. Obsidian has been associated to commercial routes of natural resources that connected different Mesoamerican archaeological sites [36, 37]. There were three important sources of obsidian in Guatemala: El Chayal, San Martín Jilotepeque and Ixtepeque. According to Nelson [38] since the early Late Preclassic period until the end of the Classical Era the obsidian from El Chayal was the most commonly used.

It should be noted that the chemical composition found in this small artifact exhibits some discrepancy to that found for obsidian glasses, which have a content of alumina at ca. $13 \%$, silica in the range $75-77 \%$ and soda + potash in the range 7-9\% [39]. Composition found in the glassy fragment approaches that found in buried glasses subjected to severe processes of corrosion associated to weathering [40]. Thus, it could be conceivable that this glassy fragment was originally an obsidian glass that has undergone a corrosion process during the burial.

\section{Funerary use of the pigmenting materials}

As described in the prior section, a noticeable amount of mono hydrate calcium oxalate has been identified in Rio Azul samples. Apart from the diagenetic and hydrothermal occurrences, oxalate minerals occur at the earth's surface in soils, unconsolidated sediments, caves and rock crusts. In all cases, the association of oxalate phases with organic matter, that provides a source of oxalate, is evident.

A first theory for explaining the formation of oxalaterich crusts as a type of rock varnish establish that these crusts are originated as by-product of the metabolic activity of the surface microflora composed of fungi, algae, bacteria and lichen colonization. These microorganisms could survive on the rock thanks to organic materials of different provenance (dead microorganisms, aerosols, etc.). In these cases, mineral nanospheres and rod-shaped crystal aggregates [41] or stromatolitic structures at microscopic scale are observed [42]. Absence of these microstructures in the studied samples permits to discard this mechanisms of formation.

A second opinion is based on the hypothesis that the oxalate salts are formed as result of the oxidative degradation of organic matter present in the surface of the rock or the mineral substrate, i.e. degradation of the organic matter that composes the animal excrements, (i.e. guano) present in caves, shelters and less frequently in outcrops. A similar mechanism has been identified on old copper coins, where recently, the authors have found copper oxalates as result of the degradation of the thin film of organic matter adhered to the coin surface when the money was in circulation [43].

A third via of formation of oxalates is based on the degradation of outdoor protective organic coatings of monuments and/or binding media of wall paintings. This mechanism has been proposed for explaining the presence of calcium and other metal oxalates in rock paintings, wall paintings and monuments [19]. In the case of the $19^{\text {th }}$ tomb this last origin should be the more plausible as organic matter of lipid type has been identified.

Together with oxalates, several long chain fatty acids have been found in samples from Rio Azul. This experimental finding suggests the hypothesis of them to be excipients of pigments used as skin colors for religious ceremonies and rituals and, therefore, discussion on the origin of the organic matter found in these samples accompanying the oxalate minerals is, at this point, of particular interest for establishing conclusions concerning the composition and use of these funerary colors.

A first possible origin of the organic matter is associated to microbiological activity. It should be noted that microbial lipids are increasingly used as biomarkers that reflect both the community structures and the dynamic 
of biogeochemical processes carried out by the microorganisms, in particular, bacteria and archaea. Bacteria have ester-linked lipids whereas archaea have phytanyl ether lipids so that the type of lipids is identificative of these two microbial domains. Lipid biomarkers can be grouped in two classes: phospholipid fatty acids and glycol lipid fatty acids. The latter include a wide range of linear and branched long chain saturated fatty acids and a number of long chain unsaturated fatty acids in the range $\mathrm{C} 14-\mathrm{C} 23$. Characteristic biomarkers of sulphatereducing bacteria include iso- and anteiso- $\mathrm{C} 15: 0$ and C17:0 and other branched phospholipid fatty acids. Lipid biomarkers of cyanobacteria, green sulphur and non-

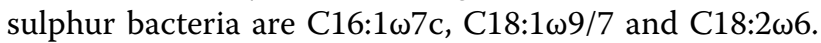
Main lipid biomarkers for Aquificales are C20:1 $\omega 9$,

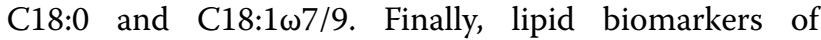
archaea include archeol, hydroxyarchaeol, among other diethers and tetraethers, and the hydrocarbons crocetane (2,6,11,15-tetramethylhexadecane) and 2,6,10,15,19-pentamethylicosane [44, 45]. Nevertheless, the series of fatty acids identified in samples from Rio Azul does not match the above mentioned characteristic biomarkers of microorganisms able to form metabolic products of lipid type.

Other possible origin for the organic matter present in these samples could be the degradation of animal excrements or guano abundantly present in caves, shelters and, less frequently, in outcrops. As reported by ShahackGross et al. [31], degraded organic matter formed from animal excrements and guano contains mainly cellulose or chitin as main component depending on the type of animal. GC-MS analysis of polysaccharides performed on samples demonstrated the absence of such biopolymers in the studied samples.

Concerning the possible origin of the organic matter found in the samples as a lipidic material intentionally added as excipient of a funerary color, Evershed et al. [46] have reviewed occurrence of fats and oils in archaeological remains and they have reported that triacylglycerols composing animal fats easily undergo loss of two or one fatty acyl moieties, which results in the appearance of mono and diacylglycerols. The latter, in turn, dramatically reduce their abundance since complete hydrolysis is rapid following the loss of one fatty acid from the triacylglycerol. As consequence of these processes, free long chain fatty acids accompanied of variable amounts of $\alpha, \omega$-dicarboxylic acids ranging from $\mathrm{C} 7$ to $\mathrm{C} 12$ have been reported as compounds usually identified in oxidized fats found in archaeological remains. The organic matter identified in the samples from the 19th tomb of Rio Azul includes, as major compounds, long chain fatty acids C16:0 and C18:0 accompanied by a notable amount of decanedioic acid and small amounts of C18:1. Absence of other fatty diacids with shorter chain should be justified by the high solubility of these compounds in aqueous media such as that resulting from the particular environmental conditions of the burial. According to these environmental conditions, it should be expected a chromatographic profile like that found in samples, which is dominated by peaks from long chain fatty acids that are significantly less prone to solubilize in aqueous media. Absence of characteristic features of triacylglycerols, identification of free fatty acid and metal-carboxylate features in the IR spectra, also supports the idea that oxidative process followed by hydrolysis and metal complexation could take place on some organic substance of lipidic type added to the pigment as cosmetic excipient. Identification of compounds of polyconjugated diene type also supports that hypothesis. These last compounds have been widely reported as well-known alteration products that are formed during ageing of fats and drying oil films [47, 48].

Identification of the type of lipid substance present in these samples is another issue closely related to the possible use and religious symbolism of the pigmenting material found in the burial. Evershed et al. [46] have reported that fatty acids commonly forming the triacylglycerols of animal fat range in carbon chain number between C40 and C54, with the C50 and C52 components the most abundant. Nevertheless, oxidative decay of animal fat produces a pattern of fatty acids dominated by those with saturated $\mathrm{C} 16$ and $\mathrm{C} 18$ chains via a combination of enzymatic and chemical hydrolysis. These researchers report that fats from ruminant animals' exhibit stearic to palmitic acid ratio $(\mathrm{S} / \mathrm{P})$ values at ca. 0.49 whereas $\mathrm{S} / \mathrm{P}$ value found in non-ruminant animals is 1.18. Vázquez et al. [49] also report low values for S/P ratio in samples of rock painting, where fat of a ruminant animal was identified as binding medium of the pigments. Interestingly, the profile of fatty acids and the $\mathrm{S} / \mathrm{P}$ value of 0.49 found in Rio Azul samples are in good agreement with the results reported by these researchers for adipose fats of ruminant animal origin found in prehistoric remains. However, S/P value obtained in the analyses carried out must be cautiously discussed taking into account that other processes can interfere. For instance, it has been demonstrated a higher volatility of steraric acid than palmitic acid that should contribute to lower the S/P ratio. On the other hand, the higher ability of palmitic acid for complexing with metal ions than stearic acid results in a selective lowering of the palmitic acid content [5]. In the Rio Azul pigments both processes should have acted in parallel, in other words, loss of palmitic and stearic acids could take place simultaneously following different mechanisms and, consequently, it is probable that their effects should be compensated themselves at least, partially. Therefore, the picture of the fate of the lipidic 
matter subjected to ageing for centuries in the 19th tomb of Rio Azul appears extremely complex and, for this reason, this result should be considered merely as an hypothesis.

Irrespectively of the cosmetic use of the pigments found in the Rio Azul 19th tomb, it is evident the importance of this finding for understanding the symbolism of funerary materials and their use in posthumous rituals in this concrete Maya region. It has been widely quoted the common practice in the ancient Mesoamerican civilizations of decorating with cosmetic pigments the body of the deceased belonging to the high-status social stratum. These pigments also took part of the funerary goods and were employed during the funerary rites and, probably during relic care rites by applying them on the body of the priest, the deceased or both [50]. Therefore, it is highly probable that the pigmenting materials found in the Rio Azul tomb had a magic symbolism as it is put in evidence by the rest of offering objects of high value found in the ceremonial ceramic dish placed next to the deceased. All them probably were used in religious rituals and funerary ceremonies. Use of lipid substances such as fats and waxes as excipients of cosmetics in ancient cultures of the Mediterranean Basin has been reported [7]. Nevertheless, no quotation has been found that reports the use of organic compounds as excipient of funerary cosmetics in Mesoamerica region. In this sense it should be noted that there are scarce studies devoted to the analytical characterization of funerary pigments in Mesoamerica [11]. Therefore, it could be tentatively suggested that these pigments had a cosmetic function both related to the high status of the deceased.

\section{Conclusions}

The study carried out provides new information concerning chemical and mineralogical composition of funerary colors in Mesoamerica by the Maya culture. Mineralogical characterization of the samples and, in particular, identification of cinnabar and haematite, suggests that the materials used for this purpose in the case of tomb 19 from Rio Azul were obtained in outcrops inside the direct cultural influence area of this archaeological site, as for instance, Uaxactún. In contrast, obsidian could be associated with commercial routes in a wider Mesoamerican area.

Although the analytical results obtained in this study are not conclusive for demonstrating the intentionally addition of an organic excipient to the funerary pigmenting materials found in the Rio Azul 19th tomb due to their high level of degradation, it cannot be completely discarded the hypothesis of their use as body colors applied on the body of the deceased or the officiant of the funerary ritual.

Irrespectively of the identification of an organic excipient the finding of the pigmenting materials itself demonstrates that red pigments played an important role in Maya funerary rituals. These pigments probably had a notably magic or religious symbolism for which they were included as offerings, in particular, in tombs of high status individuals.

\section{Abbreviations \\ ATR: Attenuated Total Reflectance; LAS: Leica Application Suite; LM: Light microscopy; CVs: Cyclic voltammograms; DFC: Digital FireWire Camera; ECF: Ethyl chloroformate; FTIR: Fourier transform infrared spectroscopy; GC-MS: Gas chromatography-mass spectrometry (GC-MS); MNAE: Museo Nacional de Arqueologia y Etnologia; SEM-EDX: Scanning electron microscopy-X-ray microanalysis; S/P: Stearic to palmitic acid ratio; SQWV: Solid state square wave voltammetry; UV-vis spectrophotometry: Ultraviolet-visible spectrophotom- etry; XRD: X-ray diffraction (XRD).}

\section{Acknowledgements}

The authors wish to thank the directors of the Museo Nacional de Arqueología y Etnología of Guatemala and LaBlanca project. The authors wish to thank Mr. Manuel Planes and Dr. José Luis Moya, technical supervisors of the Electron Microscopy Service of the Universitat Politècnica de València, and Alicia Mestre technical supervisor responsible for the X-ray Diffraction Section at the Central Service for the Support to Experimental Research of the Universitat de València.

\section{Authors' contributions}

MTDC has designed and directed the entire chemico-analytical study. She has experimentally performed analysis as well as interpreted and discussed the analytical results obtained by means of the set of analytical techniques used including LM. SEM-EDX, XRD, GC-MS, FTIR and UV-vis spectroscopies and SQWV, has performed LM, SEM-EDX, XRD and GC-MS. MLVÁP has provided and archaeo-historically documented samples as well as participated in the interpretation of the analytical results. LOC has experimentally performed analysis as well as interpreted and discussed the analytical results obtained by means of the set of analytical techniques used including LM. SEM-EDX, XRD, GC-MS, FTIR and UV-vis spectroscopies. ADC has experimentally performed analysis as well as interpreted and discussed the analytical results obtained by means of SQWV. NGF has interpreted and discussed the analytical results obtained by means of the set of analytical techniques used including LM. SEM-EDX, XRD. CVL has provided and archaeo-historically documented samples as well as participated in the interpretation of the analytical results. All authors read and approved the final manuscript.

\section{Funding}

Financial support is gratefully acknowledged from the Spanish "I + D+l MINECO" project CTQ2017-85317-C2-1-P, which is supported by the Ministerio de Economía, Industria y Competitividad (MINECO), Fondo Europeo de Desarrollo Regional (ERDF) funds and Agencia Estatal de Investigación (AEI), the Universitat de València project UV-INV-AE11-42990 and the Ministerio de Ciencia, Innovación y Universidades I+D project PGC2018-098904-B-C22.

\section{Availability of data and materials}

Available to request to the authors.

\section{Competing interests}

The authors declare that they have no competing interests.

\section{Author details}

${ }^{1}$ Institut de Restauració del Patrimoni, Universitat Politècnica de València, Camino de Vera s/n, 46022 Valencia, Spain. ${ }^{2}$ Departament d'Historia de I'Art, Universitat de València, Avda. Blasco Ibañez s/n, 46022 Valencia, Spain.

${ }^{3}$ Departament de Química Analítica, Universitat de València, Avda. Dr Moliner 
s/n, 46100 Burjassot, Spain. ${ }^{4}$ Departament d'Arts i Conservació-Restauració. Facultat de Belles Arts, Universitat de Barcelona, Barcelona, Spain.

Received: 22 January 2020 Accepted: 23 April 2020

Published online: 20 May 2020

\section{References}

1. Cabrera Castro R. Las prácticas funerarias de los antiguos teotihuacanos. In: Serrano C, editor. Manzanilla L. Prácticas funerarias en la Ciudad de los Dioses. Los enterramientos humanos de la antigua Teotihuacán. México: Instituto de Investigaciones Estéticas-Universidad Nacional Autónoma de México; 1999. p. 503-33.

2. Lucas A, Harris JR. Ancient Egyptian materials and industries. London: Edward Arnold; 1963.

3. Shortland AJ, Nicholson PT, Jackson CM. Lead isotopic analysis of eighteenth-dynasty egyptian eyepaints and lead antimonate colourants. Archaeometry. 2007;41(2):153-7.

4. Walter P, Welcomme E, Hallégot P, Zaluzec NJ, Deeb Ch, Castaing J, Veyssière P, Bréniaux R, Lévêque JL, Tsoucaris G. Early use of PbS nanotechnology for an ancient hair dyeing formula. Nano Lett. 2006;6:2215-9.

5. Cotte M, Dumas P, Richard G, Breniaux R, Walter Ph. New insight on ancient cosmetic preparation by synchrotron-based infrared microscopy. Anal Chim Acta. 2005;553(1-2):105-10.

6. Van Elslande E, Guérineau V, Thirioux V, Richard G, Richardin P, Laprévote O, Hussler G, Walter Ph. Analysis of Ancient Greco-Roman cosmetic materials using laser desorption ionization and electrospray ionization mass spectrometry. Anal Bioanal Chem. 2008;390:1873-9.

7. Gamberini MC, Baraldi C, Palazzoli F, Ribechini E, Baraldi P. MicroRaman and infrared spectroscopic characterization of ancient cosmetics. Vib Spectrosc. 2008;47:2-90.

8. Lucas A. Cosmetics, Perfumes and Incense in Ancient Egypt. J Egypt Archaeol. 1930;16:41-53.

9. Ribechini E, Modugno F, Pérez-Arantegui J, Colombini MP. Discovering the composition of ancient cosmetics and remedies: analytical techniques and materials. Anal Bioanal Chem. 2011;401:1727-38.

10. Yamada MO, Minami T, Yamada G, Tohno Y, Tohno S, Ikeda Y, Tashiro T, Kohno Y, Kawakami K. Different element ratios of red cosmetics excavated from ancient burials of Japan. Sci Total Environ. 1997;199:293-8.

11. Doménech-Carbó MT, Vázquez de Ágredos-Pascual ML, Osete-Cortina L, Doménech-Carbó A, Guasch-Ferré N, Manzanilla LR, Vidal-Lorenzo C. Characterization of prehispanic cosmetics found in a burial of the ancient city of Teotihuacan (Mexico). J Archaeol Sci. 2012;39:1043-62.

12. Vázquez de Ágredos-Pascual M.L, Vidal-Lorenzo C, Horcajada Campos P, Tiesler V. Body Color and Aromatics in Maya Funerary Rites. In: Dupey García E, Vázquez de Ágredos-Pascual, editors. Painting the Skin: Pigments on Bodies and Codices in Pre-Columbian Mesoamerica. Arizona-México: University of Arizona Press-Universidad Nacional Autónoma de México; 2018. p. 56-74.

13. Scholz F, Schröder U, Gulaboski R. Electrochemistry of immobilized particles and droplets. Berlin: Springer; 2005.

14. Doménech-Carbó MT, Casas-Catalán MJ, Doménech-Carbó A, MateoCastro R, Gimeno-Adelantado JV, Bosch-Reig F. Analytical study of canvas painting collection from the Basilica de la Virgen de los Desamparados using SEM/EDX. FT-IR, GC and electrochemical techniques. Fresenius' J Anal Chem. 2001;369:571-5.

15. Mejanelle P, Bleton J, Tchapla A, Goursaud S. Gas chromatographyemass spectrometric analysis of monosaccharides after methanolysis and trimethylsilylation. Potential for the characterization of substances of vegetal origin: application to the study of museum objects. In: El Rassi Z, editor. Carbohydrate Analysis by Modern Chromatography and Electrophoresis. Journal of Chromatography Library: Elsevier Science. Vol. 66; 2002. p. 845-902.

16. Gunasekaran S, Anbalagan G, Pandi S. Raman and infrared spectra of carbonates of calcite structure. J Raman Spectrosc. 2006;37:892-9.

17. Davis KM, Tomozawa M. An infrared spectroscopic study of water-related species in silica glasses. J Non-Cryst Solids. 1996;201:177-98.

18. Madejová J, Keckés J, Pálková H, Komadel P. Identification of components in smectite/kaolinite mixtures. ClayMinerals. 2002;37:377-88.
19. Rampazzi L, Andreotti A, Bonaduce I, Colombini MP, Colombo C, Toniolo L. Analytical investigation of calcium oxalate films on marble monuments. Talanta. 2004;63:967-77.

20. Rey C, Shimizu M, Collins B, Glimcher MJ. Resolution-enhanced Fourier transform infrared spectroscopy study of the environment of phosphate ions in the early deposits of a solid phase of calcium-phosphate in bone and enamel, and their evolution with age. I: investigations in the $\mathrm{V}_{4} \mathrm{PO}_{4}$ domain. Calcif Tissue Int. 1990;46:384-94.

21. Rey C, Shimizu M, Collins B, Glimcher MJ. Resolution-enhanced Fourier transform infrared spectroscopy study of the environment of phosphate ion in the early deposits of a solid phase of calcium phosphate in bone and enamel and their evolution with age: 2 . Investigations in the $\mathrm{v}_{3} \mathrm{PO}_{4}$ domain. Calcif Tissue Int. 1991;49:383-8.

22. Helwig K. Iron oxide pigments: natural and synthetic. In: Ashok R, editor. Artists' pigments, vol. 2., A handbook of their history and characteristicsWashington: National Gallery of Art; 1993. p. 39-95.

23. Grygar T, Bezdicka P, Hradil D, Doménech A, Marken F, Lubomir O, Cepria G. Voltammetric analysis of iron pigments. Analyst. 2002;127:1100-7.

24. Doménech A, Doménech-Carbó MT, Vázquez de Agredos-Pascual ML. Chemometric study of maya blue from the voltammetry of microparticles approach. Anal Chem. 2007;79:2812-21.

25. Doménech A, Doménech-Carbó MT, Moya M, Gimeno-Adelantado $J$, Bosch-Reig F. Identification of inorganic pigments from paintings and polychromed sculptures immobilized into polymer film electrodes by stripping differential pulse voltammetry. Anal Chim Acta. 2000;407:275-89.

26. Mazzeo R, Prati S, Quaranta M, Kendix JE, Galeotti M. Attenuated total reflection micro FTIR characterization of pigment-binder interaction in reconstructed paint films. Anal Bioanal Chem. 2008;392:65-76.

27. Montúfar López A. Los copales mexicanos y la resina sagrada del Templo Mayor de Tenochtitlán. México: Instituto Nacional de Antropología e Historia; 1997.

28. Morehart CT, Lentz DL, Prufer KM. Wood of the Gods: the ritual use of pine (Pinus Sp.) by the Ancient Lowland Maya. Lat Am Antiquity. 2005; 16:255-74.

29. Heyden D. La sangre del árbol: el copal y las resinas en el ritual mexicano. In: Rueda Smithers S, Sosa V, Martínez Baracs R, editors. Códices y Documentos sobre México. Segundo Simposio. Vol. 2 (Serie Historia). México: Instituto de Antropología e Historia, México; 2000. p. 243-70.

30. Anthony JW, Bideaux RA, Bladh KW, Nichols MC. Handbook of mineralogy. Tucson: Mineralogical Society of America; 1980.

31. Shahack-Gross R, Berna F, Panagiotis K, Weiner S. Bat guano and preservation of archaeological remains in cave sites. J Archaeol Sci. 2004;31:1259-72.

32. Arnold DE, Bohor BF, Neff H, Feinman GM, Williams PR, Dussubieux $\mathrm{L}$, Bishop R. The first direct evidence of Pre-Columbian sources of palygorskite for Maya Blue. J Archaeol Sci. 2012;39:2252-60.

33. Bundschuh J, Alvarado GD. Central America: geology, resources, and hazards, vol. 1, 2. London: Taylor \& Francis; 2007.

34. Dengo G, Levy E. Mapa metalogenético de América Central, 1:2,000.000. Central American Research Institute for Industry and Instituto Centroamericano de Investigación y Tecnología Industrial (ICAITI); 1970.

35. Gómez de Salazár, J.M. Estructura y mineralogénesis de minerales sulfurados de interés metalúrgico : Mena de Chovar (Castellón). Tomo I. Tesis Doctoral. Departamento de Metalurgia. Facultad de Ciencias Químicas. Universidad Complutense de Madrid. Madrid; 1982.

36. González, AC. Programa de conservación para el patrimonio natural y cultural para el parque nacional de Río Azul, Petén. Maestría en diseño, planificación y manejo ambiental. Facultad de Arquitectura. Universidad de San Carlos de Guatemala, Guatemala; 2006.

37. Quintana, OA. La composición arquitectónica y la conservación de las edificaciones monumentales mayas del noreste de Petén. Tesis Doctoral. Departamento de Composición Arquitectónica. Escuela Técnica Superior de Arquitectura de Valencia. Universitat Politècnica de València, Valencia; 2008.

38. Nelson, FW. El intercambio de obsidiana en las Tierras Bajas Mayas. En XVII Simposio de Investigaciones Arqueológicas en Guatemala, 2003 (E. Laporte, JP, Arroyo, B., Escobedo, H., Mejía, H.) Museo Nacional de Arqueología y Etnología, Guatemala; 2004, p. 925-35.

39. Siracuni J. SEM-EDS characterization of western Mediterranean obsidians and the Neolithic site of A Fuata (Corsica). J Archaeol Sci. 2010;37:92-106. 
40. Doménech-Carbó MT, Domenéch-Carbó A, Osete-Cortina L, Saurí-Peris MCA. Study on Corrosion Processes of Archaeological Glass from the Valencian Region (Spain) and its consolidation treatment. Microchim Acta. 2006;154:123-42.

41. Bouougri EH, Porada H, Reitner J, Gerdes G. Introduction to the special issue Signatures of microbes and microbial mats and the sedimentary record. Sed Geol. 2012;263-264:1-5.

42. García-Valles M, Vendrell-Sanz M, Molera J, Blasquez F. Interaction of rock and atmosphere: patinas in Mediterranean monuments. Environ Geol. 1998;36:137-49.

43. Doménech-Carbó MT, Álvarez-Romero C, Doménech-Carbó A, OseteCortina L, Martínez-Bazán ML. Microchemical surface analysis of historic copper-based coins by the combined use of FIB-FESEM-EDX, OM, FTIR spectroscopy and solid-state electrochemical techniques". Microchem J. 2019;148:573-81.

44. Zhang ChL. Stable carbon isotopes of lipid biomarkers: analysis of metabolites and metabolic fates of environmental microorganisms. Anal Biotechnol. 2002;13:25-30.

45. Zhang CHL, Fouke BW, Bonheyo GT, Peacock AD, White DC, Huang Y, Romanek CHS. Lipid biomarkers and carbon-isotopes of modern travertine deposits (Yellowstone National Park, USA): implications for biogeochemical dynamics in hot-spring systems. Geochimica Cosmochimica Acta. 2004;68:3157-69.
46. Evershed RP, Dudd SN, Copley MS, Berstan R, Stott AW, Mottram H, Buckley SA, Crossman Z. Chemistry of archaeological animal fats. Acc Chem Res. 2002;35:660-8

47. Mills JS, White R. The organic chemistry of the museum objects. London: Butterworths; 1987

48. Lazzari M, Chiantore O. Drying and oxidative degradation of linseed oil. Polym Degrad Stab. 1999;65:303-13.

49. Vázquez C, Maier MS, Parera SD, Yacobaccio H, Solá P. Combining TXRF, FT-IR and GC-MS information for identification of inorganic and organic components in black pigments of rock art from Alero Hornillos 2 (Jujuy, Argentina). Anal Bioanal Chem. 2008;391:1381-7.

50. Binford LR. Mortuary practices: their study and potential. In: Memoirs of the Society for American Archaeology No. 25, approaches to the social dimensions of mortuary practices. Society for American Archaeology; 1971 , p. 6-29.

\section{Publisher's Note}

Springer Nature remains neutral with regard to jurisdictional claims in published maps and institutional affiliations.

\section{Submit your manuscript to a SpringerOpen ${ }^{\odot}$ journal and benefit from:}

- Convenient online submission

- Rigorous peer review

- Open access: articles freely available online

- High visibility within the field

- Retaining the copyright to your article

Submit your next manuscript at $\boldsymbol{\nabla}$ springeropen.com 